\title{
PELAKSANAAN TANGGUNG JAWAB PELAKU USAHA TERHADAP KONSUMEN DALAM STANDAR PENYAJIAN F\&B (FOOD AND BEVERAGE) PADA RESTORAN BALI VILLA SEMINYAK*
}

\author{
Oleh \\ Deti Yustina** \\ I Wayan Wiryawan*** \\ Anak Agung Sri Indrawati**** \\ Program Kekhususan Hukum Bisnis Fakultas Hukum Universitas \\ Udayana
}

\begin{abstract}
ABSTRAK
Menurut Undang-Undang Nomor 8 Tahun 1999, Perlindungan Konsumen merupakan segala upaya menjamin adanya kepastian hukum untuk memberi perlindungan kepada konsumen. Kasus yang terjadi konsumen dirugikan oleh pelaku usaha akibat cacat pada makanan, hal ini tentu pelaku usaha tidak memenuhi standar higenis sanitasi penyajian food and beverage yang mengakibatkan konsumen mengalami kerugian seperti gangguan pada pencernaan. Permasalahan yang dibahas dalam penelitian ini adalah bentuk tanggung jawab pelaku usaha terhadap konsumen dalam hal tidak terlaksananya standard hygiene sanitasi penyajian F\&B (Food and Beverage) pada Restoran Bali Vila Seminyak dan upaya penyelesaian masalah pelaku usaha terhadap kerugian konsumen atas ketidakpuasan dalam penyajian F\&B (Food and Beverage) pada Restoran Bali Vila Seminyak.
\end{abstract}

* Makalah ilmiah ini disarikan dan dikembangkan lebih lanjut dari Skripsi yang ditulis oleh penulis atas bimbingan Pembimbing Skripsi I Dr. I Wayan Wiryawan, SH., MH dan Pembimbing Skripsi II A.A. Sri Indrawati, SH., $\mathrm{MH}$.

** Penulis Pertama : Deti Yustina adalah mahasiswi Fakultas Hukum Universitas Udayana.

*** Penulis Kedua : Dr. I Wayan Wiryawan, SH., MH adalah Dosen Fakultas Hukum Universitas Udayana.

$* * * *$ Penulis Ketiga : A.A. Sri Indrawati, SH., MH adalah Dosen Fakultas Hukum Universitas Udayana. 
Metode penelitian yang digunakan adalah metode penelitian empiris dengan menggunakan pendekatan perundang-undangan, pendekatan fakta, dan pendekatan konseptual. Sumber data dalam penelitian ini adalah Undang-Undang Nomor 8 Tahun 1999 Tentang Perlindungan Konsumen, penelitian kepustakaan dan wawancara. Tujuan penelitian untuk memahami dan menganalisis tanggung jawab pelaku usaha terhadap konsumen dalam hal tidak terpenuhinya standar penyajian food and beverage pada restoran, serta memahami dan menganalisis upaya penyelesaian pelaku usaha terhadap kerugian konsumen dalam hal tidak terpenuhinya standar penyajian food and beverage pada restoran.

Dari hasil penelitian ini dapat disimpulkan (1) bentuk tanggung jawab pelaku usaha terhadap konsumen dalam standar penyajian food and beverage yaitu ganti rugi berupa pengembalian uang, perawatan kesehatan, dan pemberian santunan. (2) upaya penyelesaian masalah pelaku usaha terhadap kerugian konsumen atas ketidakpuasan dalam penyajian food and beverage pada Restoran Bali Vila Seminyak melalui jalur non-litigasi yaitu dengan jalan mediasi.

\title{
Kata Kunci: Bentuk Tanggung jawab, Pelaku Usaha, Konsumen, Standar Penyajian
}

\begin{abstract}
According to Law number 8 of 1999, consumer protection is all efforts to ensure legal certainly to provide protection to consumers. Cases that occur when consumers are harmed by business actors due to food defects, this is indicated that the business actor does not meet the hygienic standard of serving food and beverage sanitation which results in consumers experiencing losses such as digestive disorders. The problems discussed in this study are the form of business actors responsibility to consumers if there is no standard hygiene sanitation serving $f \& b$ (food and beverage) at Bali Villa Seminyak Restaurant and dispute settlement to solve problem.

The research method used is an empirical research method using a legal approach, factual approach, and conceptual approach. The data sources used in this study are law number 8 of 1999 concerning consumer protection, library research and intervies. The
\end{abstract}


aims of this research is to study and analyse the business actor responsibility to customers if hygiene sanitation standards for serving food and beverage were not implemented in the restaurant, further to study and analyse the dispute settlement to resolve the problem regarding consumer losses for dissatisfaction of food and beverage serving in the restaurant.

The results of this study can be concluded as (1) the form of business actors responsibility towards consumers in the standard of serving food and beverage, namely compensation by giving a refunds, health care, and compensation. (2) dispute settlement to resolve this problem can be done through non-litigation channels, namely mediation.

\section{Keywords: Form of Responsibilities, Business Actor, Consumer, Standard Presentation.}

\section{PENDAHULUAN}

\subsection{Latar Belakang Masalah}

Usaha restoran saat ini semakin popular baik di pusat kota maupun dipinggiran kota. Dengan adanya perkembangan jaman yang semakin maju pola kehidupan penduduk juga mengalami perubahan. Bagi mereka yang sehari-hari sibuk berkerja hampir tidak mempunyai waktu dan tenaga untuk menyiapkan hidangan keluarga, apalagi harus menyelenggarakan dan menyiapkan sendiri jamuan makanan untuk acara tertentu. Dengan demikian mereka akan menyerahkan tanggung jawab penyediaan makanan kepada pengusaha restoran yang dapat dipercaya untuk memberikan pelayanan dalam menyiapkan makanan dan minuman. Oleh karena itu tidak mengherankan jika bidang usaha restoran mengalami perkembangan yang pesat.

Sektor industri Food and Beverage salah satu sektor usaha yang terus mengalami pertumbuhan. Seiring meningkatnya pertumbuhan jumlah penduduk di Indonesia, volume kebutuhan 
terhadap Food and Beverage pun terus meningkat. Kecenderungman masyarakat Indonesia untuk menikmati makanan ready to eat menyebabkan banyak bermunculan restoran-restoran baru dibidang makanan dan minuman. ${ }^{2}$ Oleh karena itu persaingan antar restoran pun semakin kuat. Dengan persaingan yang semakin kuat ini menuntut restoran untuk memperkuat fundamental agar restoran dapat bersaing dengan restoran lain yang sejenis. Ketika suatu restoran tidak mampu bersaing dengan restoran global akan mengakibatkan penurunan volume perusahaan sehingga perusahaan akan mengalami kebangkrutan.

Restoran memiliki tugas utama melayani para konsumen atau tamu dalam menyajikan makanan dan minuman, dalam meningkatkan kepuasan para konsumen atau tamu selain rasa yang lezat, cara penyajian dan penampilan makanan juga mempengaruhi tingkat kepuasan tamu. Tingkat kepuasan wisatawan merupakan tolak ukur tertinggi terhadap kinerja para staf restoran menawarkan berbagai menu dengan pelayanan yang profesional. Pada dasarnya pengertian kepuasan wisatawan berarti standar kinerja/kualitas pelayanan atau standar kualitas produk yang di tawarkan sekurang-kurangnya sama dengan apa yang di harapkan oleh wisatawan. ${ }^{3}$

Penyajian makanan dan minuman sebagai komponen pariwisata yang sangat penting. Bali merupakan kawasan destinasi pariwisata dunia khususnya di Badung, serta merupakan kawasan restoran. Salah satu restoran di Bali yaitu

2 Ahmadi Miru dan Sutarman Yodo, 2015, Hukum Perlindungan Konsumen, PT Raja Grafindo Persada, Jakarta, h.1-5.

3 Celina Tri Siwi Kristiyanti, 2008, Hukum Perlindungan Konsumen, Sinar Grafika, Jakarta, h.13. 
Bali Vila Restoran Seminyak. Restoran ini menyediakan berbagai jenis makanan western maupun makanan khas dari Bali sendiri. Menyajikan jenis makanan khas Bali sangat berbeda dengan makanan daerah asal wisatawan tersebut, hendaknya dapat diterima dan memberikan rasa puas kepada wisatawan. Penyajian makanan dan minuman atau yang dikenal dengan istilah food and beverage service terkait dengan adanya menu hidangan, peralatan makanan dan minum, personalia penghidang makanan dan minuman, teknik pelayanan makanan, sopan santun serta etiket makan. Dengan demikian penyajian makanan berkaitan dengan cara penataan, cara menghias makanan, cara menyajikan makanan dengan alat yang tepat serta cara menghidangkan makanan yang baik.

Dampak negatifnya dalam praktek penyajian makanan saat ini menjadi isu utama bagi upaya membangun citra rumah makan/restoran, karena pada pelaksanaan usaha jasa restoran terdapat wisatawan ataupun disebut dengan konsumen yang tidak puas dengan pelayanan dari suatu restoran karena merasa dirugikan oleh pihak restoran, dimana dalam penyajian makanan dan minuman terdapat cacat pada makanan yang di hidangkan. Produk cacat di Indonesia didefinisikan sebagai produk yang tidak dapat memenuhi tujuan pembuatannya baik karena kesengajaan atau kealpaan dalam maupun disebabkan hal-hal lain yang terjadi dalam peredarannya, atau tidak menyediakan syarat-syarat keamanan bagi manusia atau harta benda mereka dalam penggunaannya, sebagaimana diharapkan konsumen. Disini sangat dibutuhkan perlindungan untuk para wisatawan agar wisatawan tersebut merasa aman dan nyaman ketika menikmati suatu hidangan restoran, sehingga wisatawan akan berkunjung kembali ke restoran tersebut. 
Mengenai perlindungan konsumen sama halnya dengan membahas tanggung jawab pelaku usaha/tanggung jawab produk (product liability), karena pada dasarnya tanggung jawab pelaku usaha dimaksudkan untuk memberikan perlindungan kepada konsumen. Agnes M. Toar mengartikan tanggung jawab produk sebagai tanggung jawab para pelaku usaha untuk produk yang dibawanya ke dalam peredaran, yang menimbulkan atau menyebabkan kerugian karena cacat yang melekat pada makanan tersebut. 4

Berdasarkan uraian masalah diatas sangat menarik untuk di teliti dalam skripsi yang berjudul "Pelaksanaan Tanggung Jawab Pelaku Usaha Terhadap Konsumen Dalam Standar Penyajian F\&B (Food And Beverage) Restoran di Bali Villa Seminyak"

\subsection{Rumusan Masalah}

1. Bagaimana bentuk tanggung jawab pelaku usaha terhadap konsumen dalam standard hygiene penyajian F\&B (Food and Beverage) pada restoran Bali Vila Seminyak?

2. Bagaimana upaya penyelesaian masalah pelaku usaha terhadap kerugian konsumen atas ketidakpuasan dalam penyajian F\&B (Food and Beverage) pada restoran Bali Vila Seminyak?

\subsection{Tujuan penelitian}

1. Untuk memahami dan menganalisis tanggung jawab pelaku usaha terhadap konsumen dalam hal tidak terpenuhinya standard penyajian F\&B (Food and Beverage) pada restoran.

4 Shidarta, 2004, Hukum Perlindungan Konsumen Indonesia, PT Gramedia Widiasarana Indonesia, Jakarta, h. 77-80. 
2. Untuk memahami dan menganalisis upaya penyelesaian pelaku usaha terhadap kerugian konsumen dalam hal tidak terpenuhinya standar penyajian F\&B (Food and Beverage) pada restoran.

\section{ISI MAKALAH}

\subsection{Metode Penelitian}

Jenis penelitian yang dipergunakan adalah penelitian hukum yuridis empiris adalah terdiri dari penilitian terhadap identifikasi hukum dan efektivitas hukum. Sehingga dalam penyusunannya dilakukan penelitian lapangan yang memanfaatkan data-data primer dari hasil wawancara dan observasi yang didukung dengan sumber primer, sumber data sekunder, dan sumber data tersier. Pendekatan fakta dilakukan dengan meneliti kenyataan atau fakta-fakta yang ada di lapangan mengenai tanggung jawab pelaku usaha terhadap konsumen dalam standar penyajian F\&B (Food And Beverage) pada restoran.

\subsection{Hasil Analisa}

\subsubsection{Bentuk Tanggung Jawab Pelaku Usaha Terhadap Konsumen Dalam Standard Hygiene Penyajian F\&B (Food and Beverage) Pada Restoran}

Pelaku usaha sebagaimana dimaksud dalam Pasal 1 ayat (3) Undang- Undang Nomor 8 Tahun 1999 tentang Perlindungan Konsumen yang menyatakan bahwa, "Pelaku usaha adalah setiap orang perseorangan atau badan usaha, baik yang berbentuk badan hukum maupun bukan badan hukum yang didirikan dan berkedudukan atau melakukan kegiatan dalam wilayah hukum negara Republik Indonesia, baik sendiri maupun bersama-sama 
melalui perjanjian menyelenggarakan kegiatan usaha dalam berbagai bidang ekonomi."

Dan mengenai konsumen, pada Pasal 1 ayat (2) UndangUndang Nomor 8 Tahun 1999 tentang Perlindungan Konsumen yang menyatakan bahwa, "Konsumen adalah setiap orang pemakai barang dan/atau jasa yang tersedia dalam masyarakat, baik bagi kepentingan diri sendiri, keluarga, orang lain maupun makhluk hidup lain dan tidak untuk diperdagangkan.”

Pengertian pelaku usaha dan konsumen sebagaimana disebutkan menurut peraturan perundang-undangan, merupakan unsur yang berkaitan satu sama lain dalam meningkatkan mutu, kualitas dan produk suatu usaha makanan atau minuman. Mengenai pengolahan pangan yang sehat dan aman adalah dengan cara melaksanakan kaidah-kaidah dari prinsip hygiene sanitasi makanan dan minuman.

Dalam Pasal 71 Undang-undang Nomor 18 Tahun 2012 tentang Pangan yang menyatakan, bahwa keamanan pangan diartikan sebagai kondisi atau upaya yang diperlukan untuk mencegah pangan dan kemungkinan cemaran biologis, kimia, dan benda lain yang dapat menggangu, merugikan, dan membahayakan kesehatan. Pengolahan pangan yang sehat dan aman adalah dengan cara melaksanakan kaidah-kaidah dari prinsip hygiene sanitasi makanan dan minuman.

Sudah merupakan kewajiban para pelaku usaha untuk senantiasa dapat memberikan pelayanan kepada konsumen, kewajiban tersebut menimbulkan tanggung jawab. Tanggung jawab adalah suatu keadaan dimana seseorang berkewajiban menanggung segala sesuatunya, atau memberikan jawaban dan menanggung segala akibat yang disebabkannya. Mengenai tanggung jawab pelaku usaha telah dinyatakan secara tegas dalam 
Pasal 19 ayat (1) Undang-Undang Perlindungan Konsumen dimana apabila konsumen dirugikan dimana konsumen menderita kerugian berupa terjadinya kerusakan, pencemaran, atau kerugian finansial dan kesehatan karena mengkonsumsi yang diperdagangkan oleh pelaku usaha. Pada Pasal 19 ayat (2) UUPK dapat berupa pengembalian uang atau penggantian barang dan/atau jasa yang sejenis atau setara nilainya, atau perawatan kesehatan dan/atau pemberian santunan yang sesuai dengan ketentuan peraturan perundang-undangan.

Secara umum, prinsip-prinsip tanggung jawab dalam hukum dapat dibedakan sebagai berikut:

1. Kesalahan (liability based on fault);

2. Praduga selalu bertanggung jawab (presumption of liability);

3. Praduga tidak selalu bertanggung jawab (presumption of non liability);

4. Tanggung jawab mutlak (strict liability);

5. Pembatasan tanggung jawab (limitation of liability). 5

Bentuk tanggung jawab pelaku usaha Bali Vila Restoran yaitu bertanggung jawab berdasarkan prinsip tanggung jawab mutlak, tanggung jawab ini digunakan untuk "menjerat" pelaku usaha, khususnya produsen barang, yang memasarkan produknya yang merugikan konsumen. Tanggung jawab mutlak yang dimaksud yaitu produsen wajib bertanggung jawab atas kerugian yang diderita konsumen atas penggunaan produk yang dipasarkannya. Pasal 19 ayat (1) UUPK secara tegas merumuskan tanggung jawab produk ini bahwa, pelaku usaha bertanggung

5 John Pieris dan Wiwik Sri Widiarty, 2007, Negara Hukum dan Perlindungan Konsumen Terhadap Produk Pangan Kedaluwarsa, Pelangi Cendikia, Jakarta, h.34. 
jawab memberikan ganti rugi atas kerusakan, pencemaran, dan/atau kerugian konsumen akibat mengkonsumsi barang dan/atau jasa yang dihasilkan atau diperdagangkan. ${ }^{6}$

Berdasarkan keterangan menurut I Ketut Mustika, Koordinator Food And Beverage Bali Vila Restoran menjelaskan bahwa, rumah makan atau Restaurant yang di kelola sampai saat ini hanya lebih kepada F\&B Service. Mengenai tanggung jawab operasional Bali Vila Restoran, baik dalam pelayanannya maupun dalam kecelakaan yang biasanya terjadi pelaku usaha dipastikan akan memberikan perhatian yang khusus bagi pihak konsumen baik berupa ganti rugi uang maupun pengobatan apabila terjadi diare terhadap konsumen dalam mengkonsumsi makanan di restoran. (Wawancara, 18-3-2019).

\subsubsection{Upaya Penyelesaian Masalah Pelaku Usaha Terhadap} Kerugian Konsumen Atas Ketidakpuasan Dalam Penyajian F\&B (Food and Beverage) Pada Restoran

Mengenai pelaku usaha rumah makan dan restoran memiliki tanggung jawab yang besar dalam menu makanan dan minuman yang dijual kepada konsumen dan bertanggung jawab juga dalam penyajiannya. Tanggung jawab ini timbul atas dasar pelaku usaha rumah makan dan restoran mempunyai tujuan agar menu makanan dan minuman yang dijual kepada konsumen nyaman dan aman untuk dikonsumsi.

Penyelesaian sengketa alternatif atau Alternative Dispute Resolution (ADR), yang dijelaskan dalam Pasal 1 angka (10) Undang-Undang Nomor 30 Tahun 1999 Tentang Arbiterase dan ADR, yang berbunyi sebagai berikut:

${ }^{6}$ Ibid. 
"Alternatif Penyelesaian Sengketa adalah lembaga penyelesaian sengketa atau beda pendapat melalui prosedur yang disepakati para pihak, yakni penyelesaian sengketa diluar pengadilan dengan cara konsultasi, mediasi, konsiliasi, atau penilaian ahli." 7

Upaya penyelesaian sengketa ini sering digunakan dalam penyelesaian sengketa antara pelaku usaha dan konsumen. Salah satu upaya penyelesaian ini dilakukan oleh pihak Bali Villa Restoran yang menggunakan cara ini untuk tahap penyelesaian perkara.

Berikut ini upaya penyelesaian non litigasi, yaitu:

\section{a. Negosiasi}

Menurut Ficher and Ury, negosiasi merupakan komunikasi dua arah yang dirancang untuk mencapai kesepakatan terhadap kedua belah pihak memiliki berbagai kepentingan yang sama maupun yang berbeda dengan tujuan untuk mendapatkan penyelesaian atau jalan keluar dari permasalahan yang sedang dihadapi oleh kedua belah pihak.

\section{b. Mediasi}

Mediasi adalah cara penyelesaian sengketa atau masalah melalui perantaraan seorang pihak ketiga (mediator). Pihak mediator akan bertindak untuk menjembati kepentingan para pihak yang tersangkut masalah untuk mencapai kesepakatan. ${ }^{8}$

7 Az. Nasution, 1999, Hukum Perlindungan Konsumen Suatu Pengantar, Daya Widya, Jakarta, h.25.

8 Eli Wuria Dewi, 2015, Hukum Perlindungan Konsumen, Graha Ilmu, Yogyakarta, h.7. 


\section{c. Konsoliasi}

Tahap ini merupakan lanjutan dari mediasi. Mediator berubah fungsi menjadi konsoliator. Dalam hal ini konsoliator menjalankan fungsi yang lebih aktif dalam mencari bentuk-bentuk penyelesaian sengketa dan menawarkannya kepada para pihak. ${ }^{9}$

Adapun dalam Pasal 47 Undang-Undang No.8 Tahun 1999 tentang Perlindungan Konsumen memuat tentang penyelesaian sengketa di luar pengadilan, "Penyelesaian sengketa konsumen diluar pengadilan diselenggarakan untuk mencapai kesepakatan mengenai bentuk dan besarnya ganti rugi dan/atau mengenai tindakan tertentu untuk "menjamin" tidak akan terjadi kembali atau tidak akan terulang kembali kerugian yang diderita oleh konsumen." Dengan adanya Undang-Undang ini menjamin bahwa konsumen mendapatkan kompensasi akibat kesalahan yang dilakukan pelaku usaha.

Upaya penyelesaian pelaku usaha terhadap konsumen melalui jalur non litigasi yaitu dengan jalan mediasi. Dan mengenai ganti kerugian terhadap konsumen diselesaikan secara damai yang dilakukan oleh para pihak sendiri untuk mencapai kesepakatan dalam penyelesaian masalah secara damai atau penyelesaian masalah di luar pengadilan.

Berdasarkan keterangan menurut Bapak Abdul Malik, Manager operasional Bali Vila Restoran menjelaskan bahwa, jika ditemukannya masalah yang dimana dapat merugikan konsumen seperti dikarenakan penyajian makanan serta minuman yang dipesannya mengalami cacat, maka pihak restoran siap untuk memberikan perhatian yang penuh dan memberikan ganti h.8.

9 Endang Purwaningsih, 2010, Hukum Bisnis, Ghalia Indonesia, Bogor, 
kerugian kepada pihak konsumen. Pihak restoran pun memberikan perhatian yang ekstra agar kejadian tersebut tidak terulang kembali, dengan memberikan breafing kepada karyawan agar lebih memperhatikan kualitas makanan dan minuman yang disajikan, serta dilakukan pengecekan seluruh bahan-bahan makanan agar sudah sesuai dengan standar. Untuk upaya penyelesaian ganti kerugian karena makanan yang dikonsumsi konsumen yang mengakibatkan diare, pelaku usaha bertanggung jawab dengan memberikan pengobatan. Kejadian ini terselesaikan dengan cara mediasi antara konsumen dengan pihak restoran. (Wawancara, 19-3-2019).

\section{PENUTUP}

\subsection{Kesimpulan}

Bentuk tanggung jawab pelaku usaha yaitu, wajib memberikan ganti rugi atas kerusakan, pencemaran, dan/atau kerugian konsumen akibat mengkonsumsi barang dan/atau jasa yang dihasilkan atau diperdagangkan. ${ }^{10}$ Upaya penyelesaian pelaku usaha terhadap konsumen melalui jalur non litigasi yaitu dengan jalan mediasi. Dan mengenai ganti kerugian terhadap konsumen diselesaikan secara damai yang dilakukan oleh para pihak sendiri untuk mencapai kesepakatan dalam penyelesaian masalah secara damai atau penyelesaian masalah di luar pengadilan.

\subsection{Saran}

1. Masyarakat harus lebih berhati-hati menggunakan suatu produk yang diperdagangkan, karena biasanya produkproduk yang beredar di masyarakat, seringkali harga yang

${ }^{10}$ Ibid. 
relatif rendah namun dapat berakibat fatal karena berhubungan dengan kualitas makanan atau minuman yang dikonsumsi.

2. Pemerintah harus memberikan sosialisasi kepada seluruh pemilik usaha restoran, untuk pentingnya memiliki sop hygiene sanitasi penyajian food and beverage sesuai dengan peraturan perundang-undangan yang berlaku.

\section{DAFTAR PUSTAKA}

\section{A. Buku}

Ahmadi Miru dan Sutarman Yodo, 2015, Hukum Perlindungan Konsumen, PT Raja Grafindo Persada, Jakarta. h.1-5.

Az. Nasution, 1999, Hukum Perlindungan Konsumen Suatu Pengantar, Daya Widya, Jakarta, h.25.

Celina Tri Siwi Kristiyanti, 2008, Hukum Perlindungan Konsumen, Sinar Grafika, Jakarta, h.13.

Eli Wuria Dewi, 2015, Hukum Perlindungan Konsumen, Graha Ilmu, Yogyakarta, h.7.

Endang Purwaningsih, 2010, Hukum Bisnis, Ghalia Indonesia, Bogor, h.8.

John Pieris dan Wiwik Sri Widiarty, 2007, Negara Hukum dan Perlindungan Konsumen Terhadap Produk Pangan Kedaluwarsa, Pelangi Cendikia, Jakarta, h.34.

Shidarta, 2004, Hukum Perlindungan Konsumen Indonesia, PT Gramedia Widiasarana Indonesia, Jakarta, h. 77-80.

\section{B. Jurnal Ilmiah}

Gusti Ayu Nomia, 2016, Perlindungan Konsumen Akibat Tidak Terlaksananya Sanitasi Makanan dan Minuman, Jurnal Magister Hukum Udayana, diakses Jumat 29 Mei 2019: 
https://ojs.unud.ac.id/index.php/jmhu/article/view/20614/ $\underline{17689}$

Rosita Indrayati, Revitalisasi Peran Hakim Sebagai Pelaku Kekuasaan Kehakiman Dalam Sistem Ketatanegaraan Indonesia, diakses Selasa, 30 Mei 2019:

https://ojs.unud.ac.id/index.php/kerthapatrika/article/view $\angle 30089$

\section{Peraturan Perundang-undangan}

Undang-Undang Tentang Pangan, Undang-Undang Nomor 18 Tahun 2012, Lembaran Negara Republik Indonesia Nomor 227 tahun 2012, Tambahan Lembaran Negara Republik Indonesia Nomor 5360

Undang-Undang Perlindungan Konsumen, Undang-Undang Nomor 8 Tahun 1999, Lembaran Negara Republik Indonesia Nomor 42 tahun 1999, Tambahan Lembaran Negara Republik Indonesia Nomor 3821 
